\title{
Gonadotropin-Inhibitory Hormone Plays Roles in Stress-Induced Reproductive Dysfunction
}

\author{
Takeshi Iwasa*, Toshiya Matsuzaki, Kiyohito Yano and Minoru Irahara \\ Department of Obstetrics and Gynecology, Institute of Biomedical Sciences, Tokushima University Graduate School, \\ Tokushima, Japan
}

OPEN ACCESS

Edited by:

Takayoshi Ubuka, Monash University Malaysia, Malaysia

Reviewed by:

Alexander S. Kauffman, University of California

San Diego, USA You Lee Son,

Waseda University, Japan

${ }^{*}$ Correspondence: Takeshi Iwasa iwasa.takeshi@tokushima-u.ac.jp

Specialty section: This article was submitted to Experimental Endocrinology, a section of the journal Frontiers in Endocrinology

Received: 18 February 2017 Accepted: 21 March 2017 Published: 05 April 2017

Citation: Iwasa T, Matsuzaki T, Yano K and Irahara M (2017) Gonadotropin-

Inhibitory Hormone Plays

Roles in Stress-Induced

Reproductive Dysfunction. Front. Endocrinol. 8:62. doi: 10.3389/fendo.2017.00062
Physical and psychological stressors suppress hypothalamic-pituitary-gonadal axis activity and sexual behavior and consequently induce reproductive dysfunction. Recently, it has been shown that gonadotropin-inhibitory hormone $(\mathrm{Gn} l \mathrm{H})$, also called RFamide-related peptide 3 (RFRP) in mammals, which is a potent inhibitory regulator of gonadotropin-releasing hormone $(\mathrm{GnRH})$ and gonadotropin, is involved in stress-induced reproductive dysfunction. GnIH/Rfrp (the gene coding RFRP-3) expression and activity are increased by psychological and immune stress, and this alteration suppresses $\mathrm{GnRH}$ and gonadotropin secretion. Glucocorticoid acts as a mediator that interacts between stress and hypothalamic GnlH/RFRP-3. GnlH/RFRP-3 also plays important roles in stress-induced suppression of sexual behavior and infertility, and genetic silencing of $\mathrm{GnIH/Rfrp} \mathrm{completely} \mathrm{recovers} \mathrm{sexual} \mathrm{behavior} \mathrm{and} \mathrm{fertility.} \mathrm{This} \mathrm{review} \mathrm{summarizes} \mathrm{what}$ is currently known about the roles of $\mathrm{GnIH}$ in stress-induced reproductive dysfunction.

Keywords: gonadotropin-inhibitory hormone, RFRP-3, Rfrp, stress, hypothalamic-pituitary-gonadal, sexual behavior

\section{INTRODUCTION}

Humans and animals have a finite amount of energy for their activities. Therefore, if any activity has to be energetically prioritized, energy for other activities will be suppressed. Although these changes may play some role in regulation of homeostasis, they occasionally result in negative consequences for normal physiological function and accelerate some diseases. Reproductive functions are often suppressed when large amounts of energy will be used for other physiological functions because such reproductive processes are not essential for individual survival (1). Several kinds of stress, such as infection, psychological burden, and excess of exercise, are thought to be pivotal triggers of reproductive dysfunctions in humans and animals (2-4). Generally, stress activates some endocrine and immune systems, such as the hypothalamic-pituitary-adrenal axis and pro-inflammatory cytokines, to regulate homeostasis. However, such alterations act to suppress reproductive function at the same time.

Reproductive function is mainly regulated by the hypothalamic-pituitary-gonadal (HPG) axis in humans and animals. Physical and psychological stressors suppress HPG activity through inhibition of gonadotropin-releasing hormone $(\mathrm{GnRH})$ in both males and females (5-7), thereby decreasing luteinizing hormone $(\mathrm{LH})$ and follicle-stimulating hormone release from the pituitary $(8,9)$. When the relationships between stress and reproductive functions are evaluated experimentally, inflammatory stress induced by a Gram-negative bacterial cell wall component, lipopolysaccharide 
(LPS), and psychological stress induced by restraint stress are frequently used. Similar to other stressors, these stresses induce some sickness behaviors, and they also suppress HPG activity through inhibition of GnRH synthesis and secretion in several mammals and birds (10-17). In addition, it has been well established that the actions of some stress-related endocrine, neuroendocrine, and inflammatory factors, such as pro-inflammatory cytokines, corticotropin-releasing hormone, and glucocorticoid/ corticosterone, are increased by stress and that these alterations act to decrease GnRH and gonadotropin secretion in times of stress $(15,18)$. However, the results of studies have been slightly controversial, and it has been assumed that some other factors may also be involved in the stress-induced suppression of HPG activity. A breakthrough occurred in the early 21 st century when a novel RFamide peptide that directly suppresses GnRH/ gonadotropin synthesis and secretion was newly discovered (19). In birds, this neuropeptide was named gonadotropin-inhibitory hormone $(\mathrm{GnIH})$, and later studies have shown that $\mathrm{GnIH}$ and its receptor, G-protein-coupled receptor (GPR) 147, have pivotal roles in the regulation of physiological function of the HPG axis, such as GnRH pulses and surges, in many species (20-22). The mammalian orthologous gene and peptide for avian $\mathrm{GnIH}$ are called Rfrp and RFRP-3, respectively. It has been gradually shown that GnIH/RFRP-3 and GPR147 also play important roles in the stress-induced suppression of reproductive dysfunction.

This paper presents a review of what is currently known about the roles of GnIH/RFRP-3 in stress-induced reproductive dysfunction in experimental animals. The main focus is on the relationship between GnIH/RFRP-3 and the HPG axis, but the role of GnIH/ RFRP-3 in reproductive behavior under stress is also examined.

\section{THE ROLE OF GnIH/RFRP-3 IN STRESS- INDUCED SUPPRESSION OF THE HPG AXIS}

In the year 2000, Tsutsui and colleagues discovered a novel neuropeptide that actively suppresses gonadotropin release from cultured bird pituitary (19). Because this was the first demonstration of a hypothalamic factor that suppresses gonadotropin release, this neuropeptide was named GnIH based on its biological action. Thereafter, GnIHs were further identified in other vertebrates, mammals, primates, and humans (21-23). Because the identified neuropeptides possess LPXRFamide (X $=\mathrm{L}$ or $\mathrm{Q})$ motif at their C-termini, the mammalian $\mathrm{GnIH}$ orthologous gene and peptide are called Rfrp and RFRP-3, respectively. GnIH/RFRP-3 neurons project to the median eminence in birds and female sheep and suppress the secretion and synthesis of gonadotropin via GnIH/RFRP-3 receptor GPR147 under both in vivo and in vitro conditions in male birds, female rats, and female sheep (19, 22, 24, 25). GnIH/RFRP-3 neurons also project to GnRH neurons and inhibit their activity via GPR147 in birds and mammals $(22,26,27)$. Therefore, GnIH/RFRP-3 inhibits gonadotropin secretion and synthesis through direct and indirect actions on the pituitary. It has been shown that GnIH/RFRP-3 inhibits GnRHelicited gonadotropin release and decreases LH pulse amplitude in female sheep $(22,24)$, and GnIH/RFRP-3 activity is decreased by high estradiol (E2) concentrations at the time of the GnRH/LH surge in female hamsters (Figure 1A) (20,22). Similarly, elevated estrogen lowers Rfrp mRNA levels in male and female mice (28). These results show that GnIH/RFRP-3 plays important roles in the regulation of the HPG axis to maintain normal reproductive ability. On the other hand, it has recently been shown that some kinds of stresses induce acute and chronic elevations of the number of GnIH/RFRP-3-immunoreactive cells and $\mathrm{GnIH}$ gene expression in the hypothalamus and that these changes disrupt the function of the HPG axis and, consequently, suppress reproductive ability. Kirby et al. found that acute $(3 \mathrm{~h}$, measured immediately after stress) and chronic (14 days, $3 \mathrm{~h} /$ day, measured $24 \mathrm{~h}$ after the end of the last stress) immobilization stresses, common psychological stress models, lead to upregulation of Rfrp mRNA expression levels in the dorsomedial hypothalamic area, and that changes of Rfrp mRNA levels correlate negatively with serum LH levels in male rats (29). In addition, they showed that $53 \%$ of RFRP-3 neurons express glucocorticoid receptor (GR) and that adrenalectomy abolishes the chronic immobilization stress-induced increase in Rfrp expression levels (29). Similarly, corticosterone administration increases Rfrp mRNA expression levels in vitro in rHypoE23, which is an Rfrp-expressing cell line derived from rat hypothalamus (30). These effects of corticosterone on rHypoE-23 are blocked by a GR antagonist $(31,32)$. Treatment with cortisol in fish increases GnIH mRNA levels and reduces GnRH mRNA and serum LH levels (33). In addition, dexamethasone exposure during the neonatal period in female mice increases Rfrp mRNA levels, and it reduces $\mathrm{GnRH}$ mRNA levels and delays pubertal onset (34). These data indicate that hypothalamic GnIH/RFRP-3 integrates the suppressive effects of glucocorticoid on the HPG axis under psychological stress conditions. Recently, Peragine et al. showed that RFRP-3 suppresses sexual maturation in socially non-dominant female rats living in colonies, where breeding is monopolized by dominant animals (35). This result also indicates that RFRP-3 may be involved in the social stress-induced suppression of reproductive function.

Recently, we evaluated the relationship between immune stress and hypothalamic Rfrp mRNA expression levels in female rats. An injection of a septic dose $(5 \mathrm{mg} / \mathrm{kg})$ of LPS in female rats was found to increase hypothalamic Rfrp and GPR147 mRNA levels $6 \mathrm{~h}$ after injection, whereas it reduced serum LH levels and hypothalamic GnRH mRNA levels (36). In this condition, Rfrp mRNA levels were negatively correlated with GnRH mRNA and serum LH levels. Interestingly, a lower dose $(500 \mu \mathrm{g} / \mathrm{kg})$ of LPS did not change Rfrp and GPR147 mRNA levels, although it decreased serum LH levels. Similarly, Lopes et al. have shown in birds that an injection of $2 \mathrm{mg} / \mathrm{kg}$ of LPS suppressed GnRH mRNA and peptide expressions $2 \mathrm{~h}$ after injection, but did not affect $\mathrm{GnIH}$ (37). These results suggest that the underlying mechanisms of dysfunction of gonadotropin secretion are changed according to the severity of immune stress, and that changes of some reserve factors, i.e., GnIH/RFRP-3, begin to participate in the suppression of $\mathrm{GnRH}$ and gonadotropin under severe conditions. On the other hand, the factors involved in the upregulation of Rfrp in times of immune stress have not been elucidated. Although we think that not only glucocorticoid but also pro-inflammatory cytokines play some roles, further examinations are needed to clarify this 
A

Increase of estrogen level<smiles>[Te][Te]</smiles>

Decrease of GnIH action

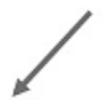

GnRH/LH surge and consequent ovulation

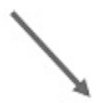

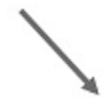

Increase of reproductive behavior
B

Stress (Increase of corticosterone level)

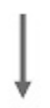

Increase of GnlH action

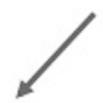

Decrease of $\mathrm{GnRH} / \mathrm{LH}$ secretion and consequent anovulation

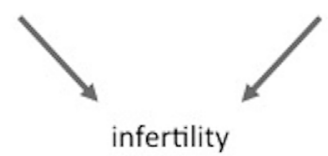

FIGURE 1 | The role of gonadotropin-inhibitory hormone (GnIH) under physiological and stress conditions. (A) GnIH participates in the control of physiological $\mathrm{GnRH} /$ luteinizing hormone $(\mathrm{LH})$ regulation. $\mathrm{GnlH}$ activity is decreased by high estrogen concentrations at the time of the $\mathrm{GnRH} / \mathrm{LH}$ surge. This alteration promotes both ovulation and reproductive behaviors and consequently increases the chance of pregnancy. (B) On the other hand, GnIH plays roles in stress-induced reproductive dysfunction. GnlH expression and activity are increased by stress, and this alteration suppresses the hypothalamic-pituitary-gonadal axis action by inhibition of $\mathrm{GnRH} / \mathrm{LH}$ secretion. It also decreases reproductive behavior and, consequently, decreases the chances of pregnancy and induces infertility. Such stress-induced changes of GnlH may be partially induced by corticosterone secreted from the adrenal gland.

hypothesis. It has also been reported that metabolic challenge, a type of energetic stress, has no effect on Rfrp mRNA levels or RFRP-3 neuronal activity in female mice (38). This result indicates that GnIH/RFRP-3 mediates some kinds of, but not all, stressors.

In summary, GnIH/RFRP-3 plays roles in the suppression of the HPG axis in times of stress (Figure 1B). Glucocorticoid may be one of the mediators that transmit the stress signal to hypothalamic GnIH/RFRP-3 neurons. However, it is also possible that the importance of GnIH/RFRP-3 in HPG dysfunction may be changed according to the kind and severity of stressor.

\section{THE ROLE OF GnIH/RFRP-3 IN STRESS- INDUCED SUPPRESSION OF REPRODUCTIVE BEHAVIORS}

As well its role in the HPG axis, GnIH/RFRP-3 also plays some roles in the regulation of reproductive behavior in some species. Johnson et al. found that central injection of RFRP-3 decreased sexual behavior in male rats (39), whereas Piekarski et al. reported that it decreased sexual motivation without affecting lordosis behavior in female hamsters $(23,40)$. Piekarski et al. also showed that administration of RFRP-3 affected neuronal activity in some hypothalamic nuclei, i.e., preoptic area, medial amygdala, and the bed nucleus of the stria terminalis, which are implicated in female sexual behaviors. Therefore, it had been assumed that a stress-induced increase of GnIH/RFRP-3 activity might suppress not only the HPG axis but it may also suppress sexual behavior and, consequently, promote infertility or subfertility. Recently, Geraghty et al. published an excellent report on this matter. In their study, they showed that chronic ( $3 \mathrm{~h} /$ day for 18 days) immobilization stress in female rats led to elevated hypothalamic Rfrp mRNA expression levels both immediately after and 4 days after the end of stress (41). This chronic stress did not affect the estrous cycle, but it decreased sexual behavior and pregnancy rates and increased embryo resorption when they mated 4 days after cessation of stress. The authors further showed that genetic silencing of Rfrp with shRNA during stress completely recovered the sexual behavior, pregnancy rate, and litter size when the females were mated after cessation of stress. These results indicate that stress-induced GnIH/RFRP-3 is related to dysfunction of sexual behavior under stress, including effects on the pregnancy rate and litter size (Figure 1B). Therefore, GnIH/RFRP-3 may be one of the clinical targets to prevent stress-induced infertility.

\section{CONCLUSION}

Recent studies have shown that GnIH/RFRP-3 plays roles in stress-induced reproductive dysfunction in many species. A stress-induced increase of GnIH/RFRP-3 actions not only suppresses the HPG axis but also disrupts sexual behavior, and these alterations have adverse effects on the pregnancy rate and litter size. These results indicate that GnIH/RFRP-3 may be one of the clinical targets to restore stress-induced infertility. However, because there are only limited data about the roles of GnIH/RFRP-3 in humans, more evaluations in humans would be needed to apply GnIH/RFRP-3 in a clinical setting.

\section{AUTHOR CONTRIBUTIONS}

All authors listed have made substantial, direct, and intellectual contributions to the work and approved it for publication.

\section{FUNDING}

This study was supported by JSPS KAKENHI Grant Number 26462526. 


\section{REFERENCES}

1. Hart BL. Biological basis of the behavior of sick animals. Neurosci Biobehav Rev (1988) 12:123-37. doi:10.1016/S0149-7634(88)80004-6

2. Yirmiya R, Avitsur R, Donchin O, Cohen E. Interleukin-1 inhibits sexual behavior in female but not in male-rats. Brain Behav Immun (1995) 9:220-3. doi:10.1006/brbi.1995.1021

3. Bonneaud C, Mazuc J, Gonzalez G, Haussy C, Chastel O, Faivre B, et al. Assessing the cost of mounting an immune response. Am Nat (2003) 161:367-79. doi:10.1086/346134

4. Pauli SA, Berga SL. Athletic amenorrhea: energy deficit or psychogenic challenge? Ann N Y Acad Sci (2010) 1205:33-8. doi:10.1111/j.1749-6632.2010. 05663.x

5. Rivier C, Rivier J, Vale W. Stress-induced inhibition of reproductive functions: role of endogenous corticotropin-releasing factor. Science (1986) 231:607-9. doi:10.1126/science. 3003907

6. Rivier C, Rivest S. Effect of stress on the activity of the hypothalamic-pituitary-gonadal axis: peripheral and central mechanisms. Biol Reprod (1991) 45:523-32. doi:10.1095/biolreprod45.4.523

7. Matsuwaki T, Kayasuga Y, Yamanouchi K, Nishihara M. Maintenance of gonadotropin secretion by glucocorticoids under stress conditions through the inhibition of prostaglandin synthesis in the brain. Endocrinology (2006) 147:1087-93. doi:10.1210/en.2005-1056

8. Du Ruisseau P, Tache Y, Brazeau P, Collu R. Effects of chronic immobilization stress on pituitary hormone secretion, on hypothalamic factor levels, and on pituitary responsiveness to LHRH and TRH in female rats. Neuroendocrinology (1979) 29:90-9. doi:10.1159/000122910

9. Gonzarez-Quijano MI, Ariznavarreta C, Martin AI, Treguerres JA, LopezCalderon A. Naltrexone does not reverse the inhibitory effect of chronic restraint on gonadotropin secretion in the intact male rat. Neuroendocrinology (1991) 54:447-53. doi:10.1159/000125933

10. Refojo D, Arias P, Moguilevsky JA, Feleder C. Effect of bacterial endotoxin on in vivo pulsatile gonadotropin secretion in adult male rats. Neuroendocrinology (1998) 67:275-81. doi:10.1159/000054323

11. Ebisui O, Fukata J, Tominaga T, Murakami N, Kobayashi H, Segawa H, et al. Roles of interleukin- $1 \mathrm{a}$ and - $1 \mathrm{~b}$ in endotoxin-induced suppression of plasma gonadotropin levels in rats. Endocrinology (1992) 130:3307-13. doi:10.1210/ endo.130.6.1597143

12. Harris TG, Battaglia DF, Brown ME, Brown MB, Carlson NE, Viguie C, et al. Prostaglandins mediate the endotoxin-induced suppression of pulsatile gonadotropin-releasing hormone and luteinizing hormone secretion in the ewe. Endocrinology (2000) 141:1050-8. doi:10.1210/endo.141.3.7393

13. Xiao E, Xia-Zhang L, Ferin M. Inhibitory effects of endotoxin on LH secretion in the ovariectomized monkey are prevented by naloxone but not by an interleukin-1 receptor antagonist. Neuroimmunomodulation (2000) 7:6-15. doi:10.1159/000026415

14. He D, Sato I, Kimura F, Akema T. Lipopolysaccharide inhibits luteinizing hormone release through interaction with opioid and excitatory amino acid inputs to gonadotropin-releasing hormone neurones in female rats: possible evidence for a common mechanism involved in infection and immobilization stress. J Neuroendocrinol (2003) 15:559-63. doi:10.1046/j.1365-2826.2003.01031.x

15. Watanobe $H$, Hayakawa Y. Hypothalamic interleukin- $1 \mathrm{~b}$ and tumor necrosis factor-a, but not interleukin-6, mediate the endotoxin-induced suppression of the reproductive axis in rats. Endocrinology (2003) 144:4868-75. doi:10.1210/ en.2003-0644

16. Owen-Ashley NT, Turner M, Hahn TP, Wingfield JC. Hormonal, behavioral, and thermoregulatory responses to bacterial lipopolysaccharide in captive and free-living white-crowned sparrows (Zonotrichia leucophrys gambelii). Horm Behav (2006) 49:15-29. doi:10.1016/j.yhbeh.2005.04.009

17. Adelman JS, Bentley GE, Wingfield JC, Martin LB, Hau M. Population differences in fever and sickness behaviors in a wild passerine: a role for cytokines. J Exp Biol (2010) 213:4099-109. doi:10.1242/jeb.049528

18. Mitchell JC, Li XF, Breen L, Thalabard JC, O’Byrne KT. The role of the locus coeruleus in corticotropin-releasing hormone and stress-induced suppression of pulsatile luteinizing hormone secretion in the female rat. Endocrinology (2005) 146:323-31. doi:10.1210/en.2004-1053

19. Tsutsui K, Saigoh E, Ukena K, Teranishi H, Fujisawa Y, Kikuchi M, et al. A novel avian hypothalamic peptide inhibiting gonadotropin release.
Biochem Biophys Res Commun (2000) 275:661-7. doi:10.1006/bbrc. 2000.3350

20. Gibson EM, Humber SA, Jain S, Williams WP III, Zhao S, Bentley GE, et al. Alterations in RFamide-related peptide expression are coordinated with the preovulatory luteinizing hormone surge. Endocrinology (2008) 149:4958-69. doi:10.1210/en.2008-0316

21. Tsutsui K, Ubuka T, Son YL, Bentley GE, Kriegsfeld LJ. Contribution of $\mathrm{GnIH}$ research to the progress of reproductive neuroendocrinology. Front Endocrinol (2015) 6:179. doi:10.3389/fendo.2015.00179

22. Tsutsui K, Ubuka T. GnIH control of feeding and reproductive behaviors. Front Endocrinol (2016) 7:170. doi:10.3389/fendo.2016.00170

23. Parhar I, Ogawa S, Ubuka T. Reproductive neuroendocrine pathways of social behavior. Front Endocrinol (2016) 7:28. doi:10.3389/fendo.2016.00028

24. Clarke IJ, Sari IP, Qi Y, Smith JT, Parkington HC, Ubuka T, et al. Potent action of RFamide-related peptide-3 on pituitary gonadotropes indicative of a hypophysiotropic role in the negative regulation of gonadotropin secretion. Endocrinology (2008) 149:5811-21. doi:10.1210/en.2008-0575

25. Murakami M, Matsuzaki T, Iwasa $T$, Yasui $T$, Irahara $M$, Osugi $T$, et al. Hypophysiotropic role of RFamide-related peptide- 3 in the inhibition of LH secretion in female rats. JEndocrinol (2008) 199:105-12. doi:10.1677/ JOE-08-0197

26. Kriegsfeld LJ, Mei DF, Bentley GE, Ubuka T, Mason AO, Inoue K, et al. Identification and characterization of a gonadotropin-inhibitory system in the brains of mammals. Proc Natl Acad Sci U S A (2006) 103:2410-5. doi:10.1073/ pnas. 0511003103

27. Ubuka T, Kim S, Huang YC, Reid J, Jiang J, Osugi T, et al. Gonadotropininhibitory hormone neurons interact directly with gonadotropin-releasing hormone-I and -II neurons in European starling brain. Endocrinology (2008) 149:268-78. doi:10.1210/en.2007-0983

28. Poling MC, Kim J, Dhamija S, Kauffman AS. Development, sex steroid regulation, and phenotypic characterization of RFamide-related peptide (Rfrp) gene expression and RFamide receptors in the mouse hypothalamus. Endocrinology (2012) 153:1827-40. doi:10.1210/en.2011-2049

29. Kirby ED, Geraghty AC, Ubuka T, Bentley GE, Kaufer D. Stress increases putative gonadotropin inhibitory hormone and decreases luteinizing hormone in male rats. Proc Natl Acad Sci U S A (2009) 106:11324-9. doi:10.1073/ pnas. 0901176106

30. Gingerich S, Wang X, Lee P, Dhillon S, Chalmers J, Koletar M, et al. The generation of an array of clonal, immortalized cell models from the rat hypothalamus: analysis of melatonin effects on kisspeptin and gonadotropin-inhibitory hormone neurons. Neuroscience (2009) 162:1134-40. doi:10.1016/j. neuroscience.2009.05.026

31. Gojska NM, Belsham DD. Glucocorticoid receptor-mediated regulation of Rfrp (GnIH) and Gprl47 (GnIH-R) synthesis in immortalized hypothalamic neurons. Mol Cell Endocrinol (2014) 384:23-31. doi:10.1016/j. mce.2013.12.015

32. Son YL, Ubuka T, Narihiro M, Fukuda Y, Hasunuma I, Yamamoto K, et al. Molecular basis for the activation of gonadotropin-inhibitory hormone gene transcription by corticosterone. Endocrinology (2014) 155:1817-26. doi:10.1210/en.2013-2076

33. Choi YJ, Habibi HR, Kil GS, Jung MM, Choi CY. Effect of cortisol on gonadotropin inhibitory hormone $(\mathrm{GnIH})$ in the cinnamon clownfish, Amphiprion melanopus. Biochem Biophys Res Commun (2017) 485:342-8. doi:10.1016/j. bbrc.2017.02.078

34. Soga T, Dalpatadu SL, Wong DW, Parhar IS. Neonatal dexamethasone exposure down-regulates GnRH expression through the GnIH pathway in female mice. Neuroscience (2012) 218:56-64. doi:10.1016/j. neuroscience.2012.05.023

35. Peragine DE, Pokarowski M, Mendoza-Viveros L, Swift-Gallant A, Cheng HM, Bentley GE, et al. RFamide-related peptide-3 (RFRP-3) suppresses sexual maturation in a eusocial mammal. Proc Natl Acad Sci U S A (2017) 114:1207-12. doi:10.1073/pnas.1616913114

36. Iwasa T, Matsuzaki T, Tungalagsuvd A, Munkhzaya M, Kawami T, Niki H, et al. Hypothalamic Kiss1 and RFRP gene expressions are changed by a high dose of lipopolysaccharide in female rats. Horm Behav (2014) 66:309-16. doi:10.1016/j.yhbeh.2014.06.007

37. Lopes PC, Wingfield JC, Bentley GE. Lipopolysaccharide injection induces rapid decrease of hypothalamic GnRH mRNA and peptide, but does not 
affect GnIH in zebra finches. Horm Behav (2012) 62:173-9. doi:10.1016/j. yhbeh.2012.06.007

38. Poling MC, Shieh MP, Munaganuru N, Luo E, Kauffman AS. Examination of the influence of leptin and acute metabolic challenge on RFRP-3 neurons of mice in development and adulthood. Neuroendocrinology (2014) 100:317-33. doi:10.1159/000369276

39. Johnson MA, Tsutsui K, Fraley GS. Rat RFamide-related peptide-3 stimulates GH secretion, inhibits LH secretion, and has variable effects on sex behavior in the adult male rat. Horm Behav (2007) 51:171-80. doi:10.1016/j. yhbeh.2006.09.009

40. Piekarski DJ, Zhao S, Jennings KJ, Iwasa T, Legan SJ, Mikkelsen JD, et al. Gonadotropin-inhibitory hormone reduces sexual motivation but not lordosis behavior in female Syrian hamsters (Mesocricetus auratus). Horm Behav (2013) 64:501-10. doi:10.1016/j.yhbeh.2013.06.006
41. Geraghty AC, Muroy SE, Zhao S, Bentley GE, Kriegsfeld LJ, Kaufer D. Knockdown of hypothalamic RFRP3 prevents chronic stress-induced infertility and embryo resorption. Elife (2015) 4:e04316. doi:10.7554/eLife.04316

Conflict of Interest Statement: The authors declare that the research was conducted in the absence of any commercial or financial relationships that could be construed as a potential conflict of interest.

Copyright $\odot 2017$ Iwasa, Matsuzaki, Yano and Irahara. This is an open-access article distributed under the terms of the Creative Commons Attribution License (CC BY). The use, distribution or reproduction in other forums is permitted, provided the original author(s) or licensor are credited and that the original publication in this journal is cited, in accordance with accepted academic practice. No use, distribution or reproduction is permitted which does not comply with these terms. 